\title{
RISK AND
}
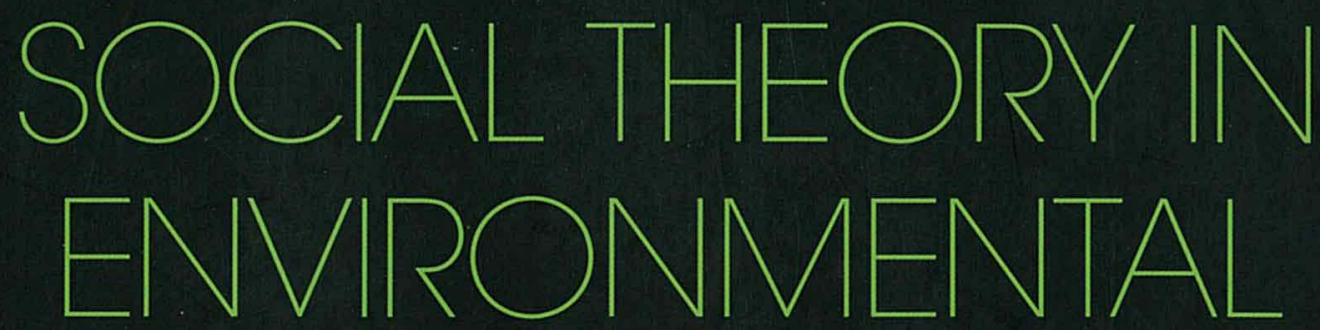

MANAGEMENT

Edited by Thomas Measham

\section{and Stewart Lockie}




$$
\begin{gathered}
\text { RISK AND SOCIAL THEORY } \\
\text { IN ENVIRONMENTAL } \\
\text { MANAGEMENT }
\end{gathered}
$$





\section{RISK AND}
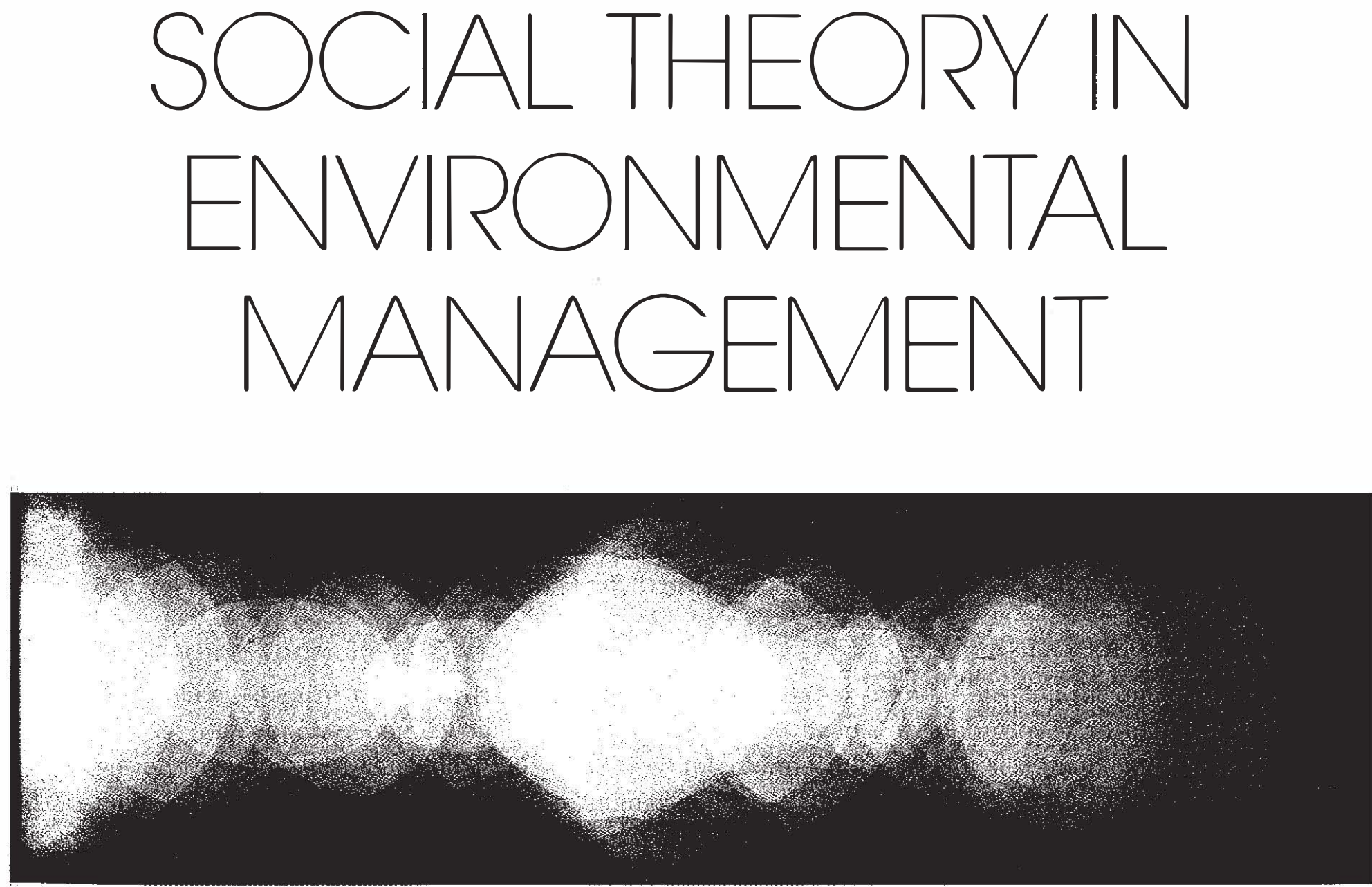

Thomas Measham

CSIRO Ecosystem Sciences

\section{Stewart Lockie}

Australian National University

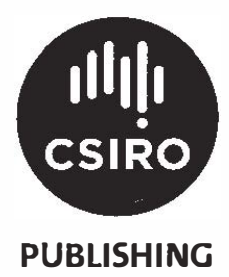


(c) Thomas G. Measham and Stewart Lockie 2012

All rights reserved. Except under the conditions described in the Australian Copyright Act 1968 and subsequent amendments, no part of this publication may be reproduced, stored in a retrieval system or transmitted in any form or by any means, electronic, mechanical, photocopying, recording, duplicating or otherwise, without the prior permission of the copyright owner. Contact CSIRO PUBLISHING for all permission requests.

National Library of Australia Cataloguing-in-Publication entry

Risk and social theory in environmental management/edited by Thomas Measham and Stewart Lockie.

9780643104129 (pbk.)

9780643104136 (epdf)

9780643104143 (epub)

Includes bibliographical references and index.

Environmental management - Australia.

Environmental risk assessment - Australia.

Risk - Sociological aspects.

Measham, Thomas B.

Lockie, Stewart.

363.70994

Published by

CSIRO PUBLISHING

150 Oxford Street (PO Box 1139)

Collingwood VIC 3066

Australia

Telephone: +61396627666

Local call: $1300-788000$ (Australia only)

Fax: $\quad+61396627555$

Email: publishing.sales@csiro.au

Web site: www.publish.csiro.au

Front cover image by iStockphoto

Set in 10/12 Adobe Minion Pro and ITC Stone Sans

Edited by Adrienne de Kretser, Righting Writing

Cover and text design by James Kelly

Typeset by Desktop Concepts Pty Ltd, Melbourne

Index by Bruce Gillespie

Printed in China by 1010 Printing International Ltd

CSIRO PUBLISHING publishes and distributes scientific, technical and health science books, magazines and journals from Australia to a worldwide audience and conducts these activities autonomously from the research activities of the Commonwealth Scientific and Industrial Research Organisation (CSIRO). The views expressed in this publication are those of the author(s) and do not necessarily represent those of, and should not be attributed to, the publisher or CSIRO.

Original print edition

The paper this book is printed on is in accordance with the rules of the Forest Stewardship Council". The FSC ${ }^{\circ}$ promotes environmentally responsible, socially beneficial and economically viable management of the world's forests.

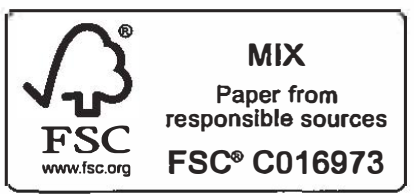




\section{Contents}

Preface vii

List of contributors ix

1 Social perspectives on risk and uncertainty: reconciling the spectacular and the mundane

Stewart Lockie and Tom Measham

\section{Part I What does social theory tell us about environmental risk and vulnerability?}

$2 \quad$ Managing risk under uncertainty

Raymond Murphy

3 Risk and environmental victimisation

Rob White

$4 \quad$ The lure of the market in tackling global warming

Fiona Haines

Colour plates

5 Complexity, uncertainty and ambiguity in inclusive risk governance

Ortwin Renn and Andreas Klinke

\section{Part II Dealing with risk at local scale}

6 Market-based resource management policy and environmental uncertainty: outsourcing risk calculation

Stewart Lockie

$7 \quad$ Women and risk: commercial wastewater injection wells and gendered perceptions of risk

Lee M. Miller

8 Development of environmental risk management plans in Great Barrier Reef catchments 
9 Shifting sands: uncertainty and a local community response to sea level rise policy in Australia

Anne Leitch and Cathy Robinson

10 Risk and climate change in Brazilian coastal cities

Leila da Costa Ferreira, Rafael D'Almeida Martins, Fabiana Barbi, Alberto

Matenhauer Urbinatti, Fernanda Oliveira de Souza, Thales Haddad Novaes de Andrade and Leonardo Freire de Mello

11 Vulnerability analysis, risk and deliberation: the Sydney Climate Change Adaptation Initiative

Tom Measham and Benjamin L. Preston

\section{Part III Governance and risk}

12 Uncertainty and ambiguity in environmental governance: water quality in Great Barrier Reef catchments Bruce Taylor, Tabatha Wallington and Cathy Robinson

13 Choice editing for the environment: managing corporate risks Jane Dixon and Cathy Banwell

14 Crisis, change and water institutions in south-east Queensland: strategies for an integrated approach

Tabatha Wallington, Cathy Robinson and Brian Head

15 Using holistic scenarios to rewrite rural futures

Tira Foran and Louis Lebel 


\section{Preface}

The idea for this volume initially evolved following a lively workshop of the Environment and Society Group attached to the Australian Sociological Association conference in December 2009. The group encouraged participation from a broad range of disciplines including human geography, political science and planning in addition to environmental sociology. This diversity was a defining characteristic of the papers presented, many of which have become chapters in this volume. Other chapters evolved from papers presented at the International Sociological Association World Congress in Gothenburg 2010, particularly an innovative session hosted by the Research Committee on Environment and Society (RC24).

The editors would like to thank Geoff Lawrence and Marcus Lane for helpful comments on developing the volume. We would also like to thank the reviewers who assisted with the peer review process including, in no particular order, Heinz Schandl, Andrew Reeson, Emma Yuen, Karin Hosking, Doug Cocks, Kirsten Maclean and Ben Harman in addition to the chapter authors who were able to assist with reviewing other chapters in the volume. 



\section{List of contributors}

Cathy Banwell is a Fellow at the National Centre for Epidemiology and Population Health, Australian National University, with a background in social anthropology and public health. She specialises in the socio-cultural determinants of health risks associated with dangerous consumptions (food, alcohol, tobacco and illicit drug use).

Fabiana Barbi is a sociologist with a Master's degree in Environmental Science at the University of São Paulo (Brazil) and York University (Canada). She is a Research Fellow of the Earth System Governance Project and a PhD candidate in Environment and Society at the State University of Campinas, Brazil.

Leila da Costa Ferreira is full Professor at the Institute of Philosophy and Human Sciences and Centre of Environmental Studies and Research at the State University of Campinas, Brazil. She is a member of the editorial boards of Journal Ambiente \& Sociedade and Annablume Press and a member of the International Sociological Association. She is Associate Faculty of Earth System Governance Project (International Human Dimensions Program) and was visiting Professor at Jiao Tong University, China in 2009.

Rafael D'Almeida Martins is a PhD candidate in Environment and Society at the State University of Campinas in Brazil and the coordinator of the Earth System Governance Research Fellows Network, Earth System Governance Project, a core project of the International Human Dimensions Program on Global Environmental Change.

Jane Dixon is a Senior Fellow and food sociologist at the National Centre for Epidemiology and Population Health, Australian National University. She has written extensively on the cultural and economic operations of supermarkets. She is currently undertaking research on the barriers to sustainable food production and consumption.

Tira Foran is a social scientist at CSIRO Ecosystem Sciences, Australia. His research background is in contentious politics and natural resource management. He has over 10 years of experience in environmental policy analysis, working in both the private sector and academia. His ongoing research interests involve how to improve planning and governance using techniques such as dialogue, participatory scenario-building and modelling.

Leonardo Freire de Mello has a $\mathrm{PhD}$ in Demography and works as a research collaborator at the Centre of Environmental Studies and Research, State University of Campinas, Brazil. He is Professor at the Paraíba Valley's University. His research focuses on the complex area of population-environment-consumption and the human dimensions of global environmental changes.

Thales Haddad Novaes de Andrade holds a PhD in Social Sciences at the State University of Campinas, Brazil and is Professor of Social Sciences at the Federal University of São Carlos. He is a Research Fellow of the National Council for Science and Technology Development, Brazil.

Fiona Haines is a criminologist and Associate Professor in the School of Social and Political Sciences at the University of Melbourne and Fellow of the College of Asia and the Pacific at the 
Australian National University. Her expertise lies in the areas of globalisation, risk, regulatory theory and regulatory reform.

Brian Head leads the evidence-based policy and sustainability research programs in the Institute for Social Science Research, University of Queensland, Australia. His recent work includes urban water policy, environmental policy and governance, regional innovation and organisational aspects of sustainability including climate change and natural resources.

Andreas Klinke serves as Associate Professor in Environmental Policy in the Division of Social Science at the Environmental Policy Institute, Memorial University of Newfoundland, Canada. He received a $\mathrm{PhD}$ in Political Science at the Darmstadt University, Germany. His research and teaching activities include international environmental politics, risk governance, deliberation and participation in environmental policy.

Louis Lebel is the current and founding director of the Unit for Social and Environmental Research at the Faculty of Social Sciences, Chiang Mai University, Thailand. He has research interests in ecology, public health, development studies and environmental governance. He is active in global environmental change science programs.

Anne Leitch (BSc, GradDipComm, MComm) has a background in science communication. She is currently a $\mathrm{PhD}$ student working on issues of climate change and environmental planning and governance with the Centre of Excellence for Coral Reef Studies at James Cook University in Queensland, and CSIRO Ecosystem Sciences.

Stewart Lockie is Professor and Head of the School of Sociology at Australian National University, co-convenor of the National Institute for Rural and Regional Australia and president of the International Sociological Association's Research Committee on Environment and Society. Professor Lockie's research addresses environmental governance, sustainable agriculture, risk and safety management in hazardous industries and social impact assessment. Recent publications include Agriculture, Biodiversity and Markets: Agroecology and Livelihoods in Comparative Perspective (Earthscan Publications, 2010).

Alberto Matenhauer Urbinatti is an undergraduate student at the Institute of Philosophy and Human Sciences, Centré of Environmental Studies and Research, State University of Campinas, Brazil.

Tom Measham is a human geographer in the Social and Economic Sciences Program of CSIRO Ecosystem Sciences and Adjunct Associate Professor at the Fenner School of Environment and Society at Australian National University. His research interests are in social learning, community engagement and regional dimensions of sustainability science.

Lee M. Miller is Associate Professor of Sociology at Sam Houston State University (USA). Dr Miller studies community responses to disasters. Her research includes community reception of displaced people from Hurricanes Katrina and Rita in Walker County, Texas, the social control of disaster survivors following Hurricane Katrina and the delayed electric power restoration after Hurricane Ike. Current research projects focus on risk and community responses to perceived environmental threats.

Raymond Murphy is Emeritus Professor at the University of Ottawa, Canada. He is the author of Sociological Theories of Education (McGraw-Hill Ryerson, 1979), Social Closure (Oxford University Press, 1988), Rationality and Nature (Westview, 1994), Sociology and Nature 
(Westview, 1997) and Leadership in Disaster: Learning for a Future with Global Climate Change (McGill-Queen's University Press, 2009).

Fernanda Oliveira de Souza is a biologist at the Institute of Biology, Centre of Environmental Studies and Research, State University of Campinas, Brazil.

Benjamin L. Preston is a senior research scientist at Oak Ridge National Laboratory (USA) and Deputy Director of Oak Ridge National Laboratory Climate Change Science Institute, where he conducts research on the societal impacts of climate change and the role of adaptation in reducing climate risk.

Steve Purbrick is a graduate engineer with Sinclair Knight Merz (Australia) working on water and environment issues. He completed a double degree in Civil Engineering and Arts (majoring in politics) at the University of Melbourne in 2008. He is currently a United Nations youth ambassador in Ghana.

Ortwin Renn is full Professor and Chair of Environmental Sociology and Technology Assessment at Stuttgart University, Germany. He directs the Interdisciplinary Research Unit for Risk Governance and Sustainable Technology Development at Stuttgart University and the nonprofit company DIALOGIK, a research institute for the investigation of communication and participation processes in environmental policy making. He also serves as Adjunct Professor for Integrated Risk Analysis at Stavanger University, Norway and as Affiliate Professor at the Harbin Institute of Technology and Beijing Normal University.

Dr Cathy Robinson is a senior scientist who leads a Research Group at the CSIRO. Her research is focused on the critical analysis of indigenous and collaborative approaches to natural resource management programs in Australia and overseas.

Nick Schofield is a Senior Executive Consultant with Sinclair Knight Merz (Australia) specialising in water, climate, natural resource management, global issues and futures. He was formerly Science Manager for Land \& Water Australia. He originally qualified with a $\mathrm{PhD}$ in Astrophysics but has spent most of his career in sustainability.

Bruce Taylor is a research scientist with the Social \& Economic Sciences Program, CSIRO Ecosystem Sciences, Australia. His main research interests are in environmental governance in agricultural and urban landscapes, particularly in policy implementation settings that involve processes of regionalisation.

Tabatha Wallington is a research scientist with the Social and Economic Sciences Program at CSIRO, and Adjunct Senior Fellow with the School of Social Science at the University of Queensland. Her research is focused on knowledge systems and governance frameworks for environmental decision-making under conditions of uncertainty.

Rob White is Professor of Criminology in the School of Sociology and Social Work at the University of Tasmania. His latest book is Transnational Environmental Crime: Toward an Ecoglobal Criminology (Routledge, 2011). 